\title{
Membangun dari Pinggiran: Tinjauan dari Perspektif Ilmu Ekonomi Regional
}

\author{
To Develop from The Periphery: \\ A Review From the Perspective of Regional Economics
}

\begin{abstract}
D. S. PRIYARSONO ${ }^{*}$
${ }^{1}$ Departemen Ilmu Ekonomi, Fakultas Ekonomi dan Manajemen, Institut Pertanian Bogor, Kampus IPB Darmaga, Bogor 16680; *Penulis korespondensi, e-mail: priyarsono@ipb.ac.id, priyarsono@yahoo.com
\end{abstract} (Diterima: 15 Oktober 2016; Disetujui: 23 Desember 2016)

\begin{abstract}
Based on the experiences of various countries that were analyzed by the World Bank, regional development strategies can be classified into three classes based on the urbanization level (low, middle, high), i. e., to increase density (to create economies of concentration), to reduce distance (to develop connectivity), and to overcome division (to handle slump areas and the accompanying problems), respectively. The policy of "to develop from the periphery" can be interpreted as a strategy to increase the intensity of economic activities particularly in rural areas in order to create economies of concentration, i.e., cost savings and other benefits that are created by the concentration of economic activities in a region. This policy has been embarked simultaneously with a very big scale of infrastructures development, especially those related to transportation (roads, seaports, and airports). This article reports the results of a literature survey on regional development theories that are related with the policy. This article also discusses the Indonesian economic situations in which the policy has been implemented. In the later part of the article several research questions are formulated suggesting directions of further studies for empirically testing the hypotheses that can be derived from the research questions, especially those related with the implementation of "to develop from the periphery" policy.
\end{abstract}

Keywords: economies of concentration, interregional connectivity, regional development strategy

\begin{abstract}
ABSTRAK
Berdasarkan pengalaman berbagai negara yang dianalisis oleh Bank Dunia, strategi pembangunan wilayah dapat dibedakan menurut tingkat urbanisasinya (rendah, sedang, dan tinggi), yakni berturut-turut strategi membangun kepadatan (menciptakan economies of concentration), strategi mengurangi jarak (membangun connectivity), dan strategi mengatasi penyekatan (menangani kawasan kumuh dan berbagai persoalan yang menyertainya). Kebijakan "membangun dari pinggiran" dapat ditafsirkan sebagai strategi meningkatkan intensitas kegiatan-kegiatan ekonomi terutama di daerah pedesaan untuk menciptakan economies of concentration, yakni penghematan yang timbul dari berkumpulnya kegiatan-kegiatan ekonomi di suatu wilayah. Kebijakan ini dibarengi dengan upaya besar-besaran membangun infrastruktur, khususnya yang berkaitan dengan transportasi (jalan raya, pelabuhan laut, dan pelabuhan udara). Artikel ini melaporkan hasil studi pustaka tentang teori pembangunan wilayah yang berkaitan dengan kebijakan tersebut. Selanjutnya, artikel ini juga membahas situasi perekonomian Indonesia di sekitar penerapan kebijakan tersebut. Pada bagian akhir dikemukakan beberapa pertanyaan yang
\end{abstract}


dapat ditindaklanjuti dengan perumusan hipotesis dan pengujian-pengujiannya berdasarkan penelitian empiris, khususnya yang berkaitan dengan penerapan kebijakan "membangun dari pinggiran".

Kata kunci: keterhubungan antarwilayah, penghematan akibat konsentrasi, strategi pembangunan wilayah

\section{PENDAHULUAN}

Konsep "membangun dari pinggiran" ramai dibicarakan publik pada tahun 2014 ketika Ir. Joko Widodo, saat itu calon presiden, mencanangkan serangkaian agendanya yang dikenal sebagai Nawa Cita (sembilan agenda). Agenda "membangun dari pinggiran" muncul pada urutan ketiga, selengkapnya berbunyi "Membangun Indonesia dari pinggiran dengan memperkuat daerah-daerah dan desa dalam kerangka negara kesatuan".

Konsep tersebut sangat menarik untuk ditinjau dari berbagai perspektif. Khusus dari perspektif Ilmu Ekonomi Regional, konsep tersebut menjadi istimewa karena tergolong amat langka dan amat jarang didiskusikan dalam forum-forum akademis. Dalam ranah publik yang lebih luas, misalnya bila kita gunakan mesin pelacak (search engine) dalam internet dengan kata kunci to develop from the periphery, maka yang kemungkinan besar muncul adalah judul-judul makalah tentang pembangunan negara-negara terbelakang di kawasan Eropa Timur. Tentulah makna to develop from the periphery dalam konteks itu berbeda dengan makna yang dimaksudkan dalam butir ketiga Nawa Cita.

Sebaliknya, bila kata kunci yang digunakan dalam penelusuran adalah membangun dari pinggiran, maka laman dan dokumen yang dimunculkan mesin pelacak dalam internet akan memunculkan banyak butir, boleh dikatakan semuanya terkait dengan Nawa Cita. Dengan demikian, kembali dapat disimpulkan bahwa konsep "membangun dari pinggiran" adalah khas Indonesia dan maknanya berbeda dengan konsep to develop from the periphery. ${ }^{3}$

Makalah ringkas ini dimaksudkan untuk melaporkan hasil telaah pustaka (literature survey) sebagai upaya untuk memahami apa yang sesungguhnya dimaksudkan dalam butir ketiga Nawa Cita tersebut dari sudut pandang Ilmu Ekonomi Regional. Untuk itu akan dipaparkan beberapa teori pembangunan regional yang cukup relevan bagi konteks Indonesia khususnya yang berkaitan dengan konsep "membangun dari pinggiran". Adapun bahasan dengan latar belakang permasalahan yang sama tetapi yang lebih bersifat analisis kuantitatif (simulasi berbagai skenario dengan model basis ekonomi) untuk menjajaki sejauh mana keberhasilan kebijakan tersebut dapat diperiksa pada laporan Priyarsono (2016).

Dalam buku teks yang cukup baku tentang pembangunan ekonomi regional yang berjudul Regional Economic Development: Analysis and Planning Strategies (Stimson et al., 2006) dibahas secara cukup rinci beberapa teori pokok dan model-model pembangunan ekonomi regional dan evolusi strategi-strategi pembangunan regional, mulai dari era 1970-an hingga era dewasa ini. ${ }^{4}$ Berikut ini diringkaskan butir-butir pentingnya.

Pembangunan ekonomi regional dapat dipandang sebagai produk dan proses. Produk yang dimaksud di sini adalah hasil pembangunan ekonomi, misalnya penciptaan kesempatan kerja, kemakmuran, investasi, standar hidup, standar lingkungan kerja, infrastruktur, dan hal-hal lain yang berkaitan dengan kehidupan, pekerjaan, dan investasi

\footnotetext{
${ }^{3}$ Untuk konteks Eropa, periksa Capello \& Fratesi (2011). Untuk konteks Aceh dan Papua, periksa Hill (2014).

${ }^{4}$ Sebagai pembanding, periksa Capello (2009, 2016).
} 
pada suatu wilayah (region). Adapun yang dimaksud dengan proses dalam hal ini adalah serangkaian kebijakan, perencanaan, analisis, strategi, dan alokasi sumber daya untuk pendukungan industri, pembangunan infrastruktur, pembinaan tenaga kerja, dan pengembangan pasar. Dengan demikian, persoalan utamanya adalah bagaimana memastikan bahwa proses tersebut menghasilkan produk seperti yang diharapkan.

Dalam perspektif teori ekonomi neoklasik, pembangunan ekonomi regional kemudian dimaknai sebagai upaya memfasilitasi proses penciptaan output $(Q)$ yang dimodelkan sebagai fungsi produksi $Q=f$ $(K, L, T, \ldots)$ dengan $K$ capital, $L$ labor, dan $T$ technology. Upaya tersebut dilaksanakan oleh pemerintah daerah atau organisasi/komunitas dengan cara stimulasi (merangsang) kegiatan bisnis dan/atau penciptaan kesempatan kerja. Tentu saja, agar pemahaman menjadi lebih lengkap, perspektif ini perlu diperluas dengan melibatkan berbagai aspek lain seperti faktorfaktor sosio-kultural yang terukur secara kualitatif dan kuantitatif. Merangkum diskusi tersebut, Stimson et al. (2006) merumuskan definisi sebagai berikut.

... Regional economic development is the application of economic process and resources available to a region that results in the sustainable development of, and desired economic outcomes for a region and that meet the values and expectations of business, of residents and of visitors.

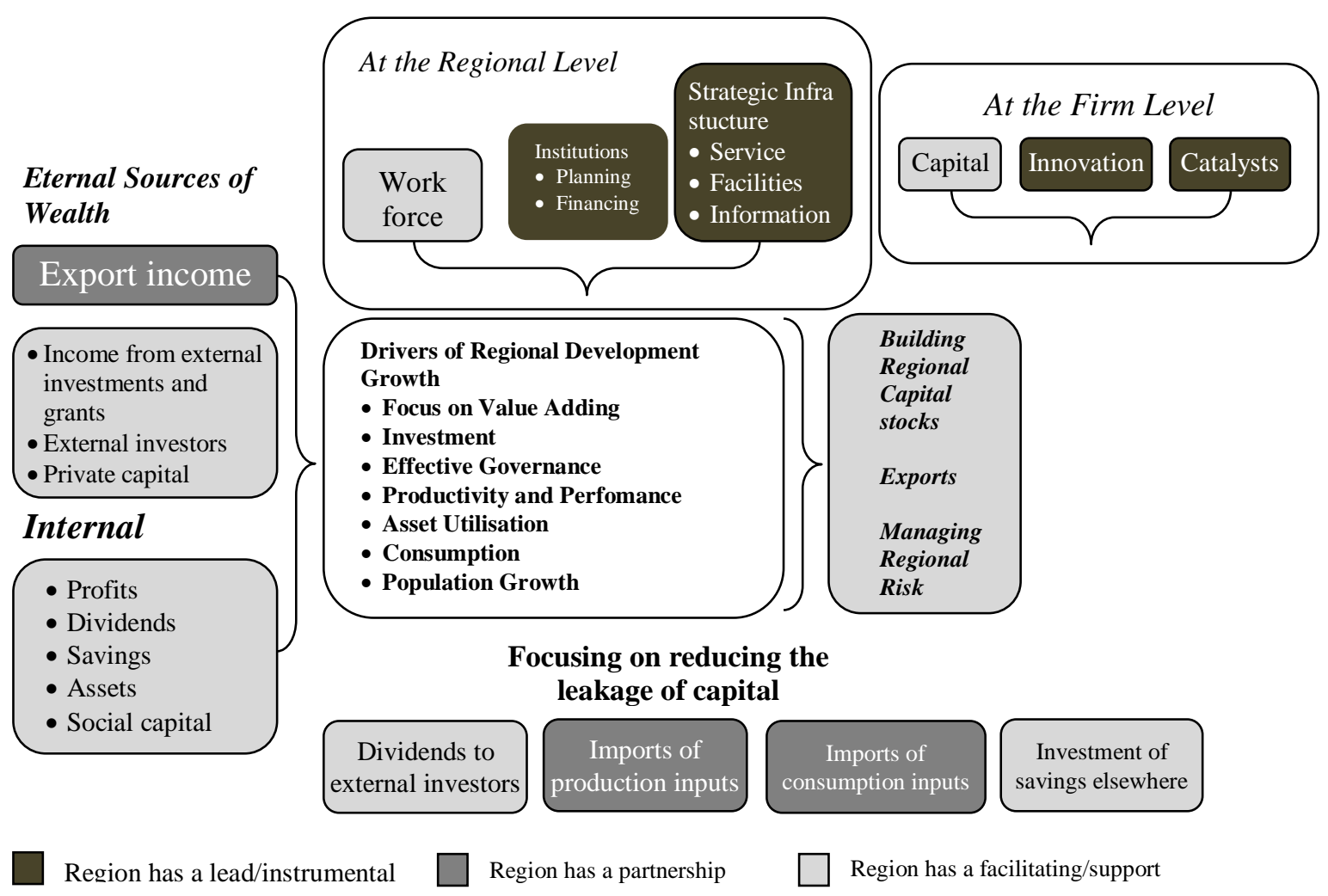

Gambar 1. Model proses pembangunan ekonomi regional Sumber: Stimson et al. (2006).

Teori ekonomi berkembang secara evolusioner. Pada awalnya, seperti yang dimodelkan dalam Teori Ekonomi Neoklasik, proses ekonomi diandaikan berlangsung seperti pada sebuah titik atau pada hamparan bidang yang homogen. Kalau pun ada dua hamparan bidang yang berbeda dalam hal perbandingan kandungan kapital dan tenaga kerja, maka proses ekonomi jangka panjang, mekanisme harga, dan mekanisme akumulasi kapital diramalkan akan mengarahkan situasi pada titik konvergensi, yakni kedua hamparan bidang itu 
pada akhirnya akan menjadi hamparan bidang yang homogen dalam arti nisbah kapital berbanding tenaga kerja menjadi seragam. Ramalan teori ini tidak mampu menjelaskan keragaman antarlokasi, sesuatu yang sesungguhnya adalah situasi spasial yang sangat alamiah. Namun, teori terus berkembang dengan setahap demi setahap mengakomodasikan aspek-aspek baru seperti gejala-gejala ketidaksempurnaan pasar akibat adanya eksternalitas dan penghematan akibat skala (economies of scale).

Teori-teori pembangunan regional bersandar pada Ilmu Ekonomi Regional yang secara eksplisit mempertimbangkan fakta ketidakseragaman sebaran sumber daya alam (mengakui adanya natural-resource advantages), timbulnya penghematan akibat berkumpulnya kegiatan-kegiatan ekonomi pada suatu lokasi (economies of concentration), dan adanya biaya transportasi dan komunikasi. Di samping itu, teori-teori pembangunan regional juga mempertimbangkan pengaruh faktor-faktor sosial, budaya, dan kelembagaan.

Salah satu teori yang paling awal dibangun dalam Ilmu Ekonomi Regional adalah Teori Basis Ekonomi (Economic Base Theory). Diasumsikan bahwa kegiatan ekonomi dalam sebuah wilayah dapat dipilah menjadi dua, yakni: (1) komponen non-basis yang melayani kebutuhan konsumsi penduduk lokal, dan (2) komponen basis yang menghasilkan barang dan jasa untuk konsumsi di luar wilayah tersebut. Tentu saja, asumsi itu bersifat ideal; dalam dunia nyata pemilahan secara tegas seperti itu sulit terjadi. Teori Basis Ekonomi meramalkan bahwa pembangunan terjadi melalui perluasan sektor basis ekonomi karena pembangunan demikian mempunyai efek pengganda (multiplier effect). Perluasan sektor basis ekonomi menarik aliran dana masuk ke wilayah tersebut. Selanjutnya aliran dana itu membangkitkan konsumsi lokal yang berarti meningkatkan pendapatan pemasok lokal. Kemudian, sebagian dari tambahan dana masuk ini digunakan untuk konsumsi barang dan jasa lokal. Demikianlah proses ini berlangsung terus-menerus sehingga menciptakan pembangunan ekonomi, yakni pertumbuhan kesempatan kerja, pendapatan, output produksi dan nilai tambah sesuai dengan besaran efek pengganda yang ditimbulkan.

Teori pembangunan wilayah yang amat terkenal berikutnya adalah Teori Kutub-kutub Pertumbuhan. Teori ini mengajukan buah pikiran bahwa strategi pembangunan ekonomi perlu memfokuskan investasi pada suatu sektor tertentu, yakni kutub pertumbuhan, atau sektor pertumbuhan, untuk memulai perputaran roda pembangunan. Lazimnya, kutub pertumbuhan suatu wilayah adalah industri dasar utama wilayah tersebut. Ketika kutub ini mulai berkembang, maka ia akan menarik sektor yang ada di belakangnya dan mendorong sektor di depannya. Artinya, sektor kutub yang berkembang membutuhkan pasokan input dari sektor-sektor lain; di pihak lain sektor itu memasokkan output produksinya dengan volume yang lebih besar kepada sektor-sektor yang membutuhkan produk itu. Proses ini sering disebut sebagai import substitution, yakni menggantikan impor dengan produk hasil wilayah itu sendiri.

Dalam konteks multiregional dengan kebijakan publik yang tepat, pusat-pusat kota dapat menjadi kutub-kutub pertumbuhan. Banyak negara sedang berkembang, termasuk Indonesia, menerapkan strategi ini untuk mendesentralisasikan pertumbuhan ekonomi pusat ke daerah-daerah. Sebagai contoh, bila ada rencana mengembangkan wilayah Sulawesi Utara, maka pemerintah pusat dapat menanamkan investasi publik pada suatu lokasi tertentu di wilayah itu, misalnya fasilitas pengolahan hasil laut di Kota Bitung. Intinya, investasi itu harus terpusat di lokasi tertentu dan bukan disebarkan merata ke semua kecamatan di Provinsi Sulawesi Utara. Lokasi tertentu itu disebut kutub pertumbuhan. Di seputar kutub pertumbuhan terdapat daerah belakang (hinterland) yang diharapkan menerima dampak positif dari penghematan yang tercipta karena terpusatnya kegiatan ekonomi di suatu lokasi tertentu (economies of concentration). Dampak positif itu disebut spread effects. Di pihak lain, ada dampak negatif yang dapat 
timbul dari adanya pusat pertumbuhan itu, yakni timbulnya kelangkaan input-input produksi lokal yang meningkatkan hargaharganya yang pada gilirannya mengurangi efisiensi ekonomi wilayah itu. Dampak negatif itu disebut backwash effects. Dalam jangka panjang perlu dipastikan bahwa efek positif lebih besar daripada efektif negatif yang ditimbulkan oleh investasi publik tersebut.

Salah satu teori yang paling sering diterapkan untuk pembangunan ekonomi regional adalah accumulative causation theory (teori penyebaban akumulatif). Teori ini menekankan peranan fokus pasar dan metode yang tepat bagi suatu wilayah untuk menarik kapital, tenaga terampil dan tenaga berkeahlian dalam rangka membangun daya saing yang mengungguli daerah-daerah lain. Langkah awal yang diperlukan untuk pembangunan wilayah, menurut teori ini, adalah penetapan sektor basis dan lokasi basis. Kapital dan perusahaan diundang masuk ke wilayah itu untuk menggarap sektor basis dan lokasi basis tersebut. Akibatnya, kesempatan kerja diperluas dan ukuran populasi membesar. Seiring dengan itu jumlah tenaga kerja terampil yang masuk ke wilayah itu meningkat. Maka, permintaan barang dan jasa sektor non-basis juga meningkat. Kesejahteraan penduduk daerah itu meningkat. Perolehan pemerintah dari pajak di daerah itu meningkat. Penyediaan infrastruktur lokal oleh pemerintah bisa ditingkatkan. Demikianlah proses itu berulang secara akumulatif. Yang kritis dalam penerapan teori ini adalah kelangkaan wirausaha dan jiwa kewirausahaan, pengembangan semangat pembelajaran dan pembangunan pendidikan, pengembangan kelembagaan serta kesediaan untuk menggunakan teknologi baru. Di samping itu, perlu dipastikan bahwa ongkos produksi di wilayah itu cukup rendah sehingga menghasilkan daya saing (comparative advantage) yang tinggi relatif terhadap wilayah-wilayah lainnya.

Baik teori basis ekonomi, teori kutub pertumbuhan maupun accumulative causation menekankan perlunya mengundang perusahaan baru untuk membangun industri di wilayah yang akan dibangun. Berbagai upaya dilakukan untuk meningkatkan daya tarik wilayah dalam mengundang masuk perusahaan baru, mulai dari penyediaan infrastruktur, penyederhanaan prosedur perizinan, penyediaan insentif keringanan pajak, dan sebagainya. Cukup banyak studi yang mempelajari keefektifan dan dampak positif dan negatif dari upaya-upaya itu.

Di pihak perusahaan, pemilihan lokasi kegiatan usahanya (lokasi pabrik, lokasi kantor, lokasi gedung untuk pergudangan, dan sebagainya) lazimnya ditetapkan berdasarkan pertimbangan biaya minimum dan atau pertimbangan penerimaan (revenue) maksimum. Bergantung pada jenis usahanya, peminimuman biaya dapat berarti peminimuman biaya transportasi atau pengangkutan barang, baik input maupun output. Demikian pula, bergantung pada jenis usahanya, pemaksimuman revenue dapat berakibat perusahaan berusaha mendekatkan diri pada lokasi berkumpulnya perusahaanperusahaan lain untuk menikmati penghematanpenghematan (agglomeration economies); atau justru sebaliknya, perusahaan berusaha menjauh dari perusahaan-perusahaan lain untuk menghindari persaingan lokasional (misalnya, dalam konteks memperebutkan pelanggan).

Di pihak rumah tangga, pemilihan lokasi mukim dan lokasi kegiatan ekonomi dapat berdasarkan peminimuman biaya transportasi dan atau pemaksimuman kenyamanan yang tersedia oleh karena adanya berbagai fasilitas (amenities). Berbagai kemajuan dalam teknologi informasi dan komunikasi ikut pula menentukan perilaku rumah tangga maupun perilaku perusahaan dalam memilih lokasi mukim dan lokasi kegiatan ekonomi.

Interaksi antara perilaku perusahaan dan perilaku rumah tangga menghasilkan pola tata ruang perkotaan dan pola lokasional antarkota. Central Place Theory menjelaskan pola-pola lokasional kegiatan-kegiatan ekonomi, baik yang dipicu oleh perilaku perusahaan, perilaku rumah tangga, maupun perilaku pemerintah. Antara lain teori ini meramalkan terjadinya pola lokasional yang hirarkis di antara kota-kota. 
Jumlah tempat pusat (central place, dapat berupa kota besar) lebih kecil daripada jumlah tempat non-pusat (kota-kota kecil). Kegiatankegiatan ekonomi di kota besar lebih besar jumlahnya dan lebih beragam-ragam bila dibandingkan dengan kota-kota yang lebih kecil.

Kota-kota kecil "melayani" kota-kota yang lebih besar dalam arti memasok inputinput produksi yang lebih hulu; sebaliknya, kota-kota besar memasok kota-kota kecil dengan produk-produk yang lebih hilir. Inovasiinovasi produksi yang menghasilkan barangbarang bernilai tinggi berlangsung di kota-kota besar yang lebih maju. Kota-kota kecil menghasilkan barang-barang yang lebih murah dengan teknologi yang lebih usang. Demikianlah beberapa ramalan Central Place Theory yang dapat menjadi acuan dalam perumusan kebijakan lokasi.

Dewasa ini lahir konsep yang dianggap mampu mewakili semua upaya pembangunan ekonomi, yakni meningkatkan competitiveness atau daya saing. Upaya tersebut tidak terbatas pada keputusan-keputusan lokasional melainkan mencakup juga upaya-upaya lainnya termasuk kolaborasi, kerja sama strategis, kemitraan, resource sharing (berbagi sumber daya) dan sebagainya. Competitiveness dibutuhkan untuk mencapai sustainable regional development (pembangunan wilayah yang berkelanjutan), namun perlu disertai dengan kepemimpinan yang kuat, kebijakan publik yang tepat dan efektif, inovasi, pertumbuhan penduduk, dan substitusi impor. Dengan kata lain, pembangunan ekonomi regional mengandung unsur-unsur daya saing usaha, kebijakan publik, dan unsur-unsur kelembagaan atau regional milieu (lingkungan regional) yang mencakupi social capital, loyalty and learning regions, power relations and controls in organizations, and organizational culture, norms and rules (Stimson et al., 2006).

Dengan mempertimbangkan pelajaranpelajaran yang telah terakumulasi dalam teori ekonomi regional (regional economic theories) dan praktik pembangunan ekonomi regional (regional economic development practices), Bank Dunia menyarankan tiga strategi pendekatan pembangunan regional berdasarkan tingkat urbanisasi (urbanization level) suatu wilayah, yakni rendah, sedang, dan tinggi (World Bank, 2009). Wilayah terbelakang dengan tingkat urbanisasi rendah memerlukan strategi membangun kepadatan (menciptakan economies of concentration). Untuk wilayah dengan tingkat urbanisasi menengah, strategi yang disarankan adalah strategi mengurangi jarak (membangun connectivity). Adapun wilayah dengan tingkat urbanisasi tinggi disarankan menerapkan strategi mengatasi penyekatan (menangani kawasan kumuh dan berbagai persoalan yang menyertainya). Pada bagian sintesis, pembahasan tentang hal ini akan diperdalam lebih lanjut.

\section{Situasi di Sekitar Penerapan Konsep "Membangun dari Pinggiran"}

Dari awal hingga pada titik ini teori-teori pembangunan regional yang dibahas di sini menekankan perlunya langkah-langkah strategis berikut ini untuk membangun suatu perekonomian regional: rumuskan kompetensi utama (core competencies) wilayah yang dibangun yang terwujud dalam perumusan sektor andalan dan tempat pusat (central place, growth pole), konsentrasikan sumber daya dan sediakan berbagai infrastruktur untuk memfasilitasi pertumbuhan dan peningkatan daya saing. Semua itu dilakukan dalam rangka mencapai tujuan mewujudkan pembangunan berkelanjutan (sustainable development). Walaupun dalam konsep sustainable development terkandung secara implisit perlunya pemerataan pembangunan, sedikit sekali pembahasan yang menyangkut upayaupaya sistematik, terencana, dan terukur untuk memastikan pemerataan pembangunan tersebut. $^{5}$

5 Debat panjang tentang pembangunan yang cenderung berbias ke kota (urban bias) telah didokumentasikan antara lain oleh Corbridge \& Jones (2009). Untuk kasus Indonesia, lihat Marcus \& Asmorowati (2006). 
Penerapan konsep "membangun dari pinggiran" dewasa ini dilingkupi oleh situasi semangat kebijakan fiskal yang menekankan pembangunan infrastruktur khususnya dengan tujuan mengembangkan konektivitas wilayahwilayah pinggiran dengan wilayah-wilayah yang secara ekonomis lebih berkembang. Dengan demikian, pembangunan infrastruktur tersebut terfokus pada pembangunan prasarana dan sarana transportasi seperti jalan raya (termasuk jalan tol), jembatan, bandar udara, pelabuhan laut (secara lebih luas disebut "tol laut"), dan sebagainya, di samping infrastruktur-infrastruktur lainnya. Kebijakan ini menekankan pentingnya wawasan jangka panjang, dalam arti bahwa imbalannya (returns on investment) baru dapat dipetik lama setelah investasi ditanamkan. Pilihan ini menimbulkan permasalahan tersendiri dalam pengelolaan fiskal yang tidak ringan serta pengelolaan kepercayaan publik yang cukup berisiko.

\section{Anggaran Infrastruktur}

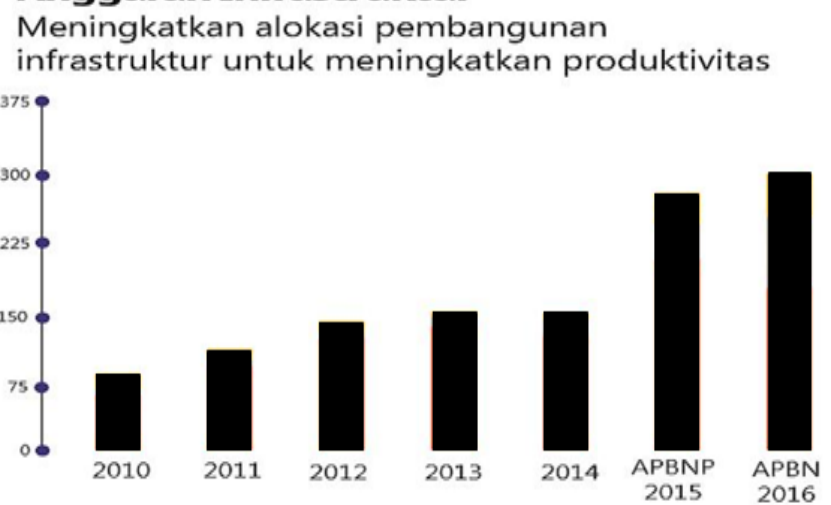

Gambar 2. Anggaran infrastruktur 2010-2016

Sumber: http://bisniskeuangan.kompas.com/read/2016/03/22/060000726/Jokowi.SBY.dan.Infrastruktur (Diunduh 22 Desember 2016)

Pada Gambar 2 terlihat bahwa alokasi dana APBN untuk pembiayaan infrastruktur secara konsisten naik dan secara tajam melonjak dalam dua tahun terakhir ini. Demikian pula, persentasenya terhadap PDB juga terus meningkat, walaupun dalam perbandingan secara internasional pembangunan infrastruktur di Indonesia masih tergolong tertinggal. Untuk pembahasan persoalan ini, lihat misalnya Priyarsono (2014).

Situasi kedua yang sangat terasa dalam penerapan konsep "membangun dari pinggiran" dewasa ini adalah melonjaknya alokasi anggaran dalam APBN untuk "Dana Desa". Sejalan dengan terbangunnya konektivitas daerah-daerah terbelakang dengan daerahdaerah pusat kegiatan ekonomi melalui pembangunan infrastruktur (sarana dan prasarana transportasi), investasi publik di daerah pedesaan digalakkan. Dengan demikian stimulasi ganda dilakukan secara serentak, yakni membuka konektivitas dan mendorong kegiatan ekonomi di daerah tertinggal yang dalam hal ini direpresentasikan oleh daerah pedesaan.

Dana Desa diwujudkan dalam bentuk hibah dari Pemerintah Pusat langsung ke tiap desa di Indonesia dalam besaran merata mendekati nilai sekitar Rp 1 Miliar per desa. Dengan jumlah desa se-Indonesia yang mencapai angka 72,944 [Gambar 3], total jumlah Dana Desa per tahun dapat mencapai angka yang sangat fantastis. Sejauh ini belum ada hasil studi komprehensif yang dipublikasikan yang melaporkan efektivitas proyek besar ini. Namun demikian, beberapa laporan jurnalistik membahas indikasi-indikasi tentang berbagai kesulitan dalam pengelolaan dana sebesar itu. Salah satu masalah utamanya berakar pada kapasitas yang terbatas yang dimiliki oleh sebagian besar desa untuk pengelolaan proyek yang bernilai sebesar itu. 


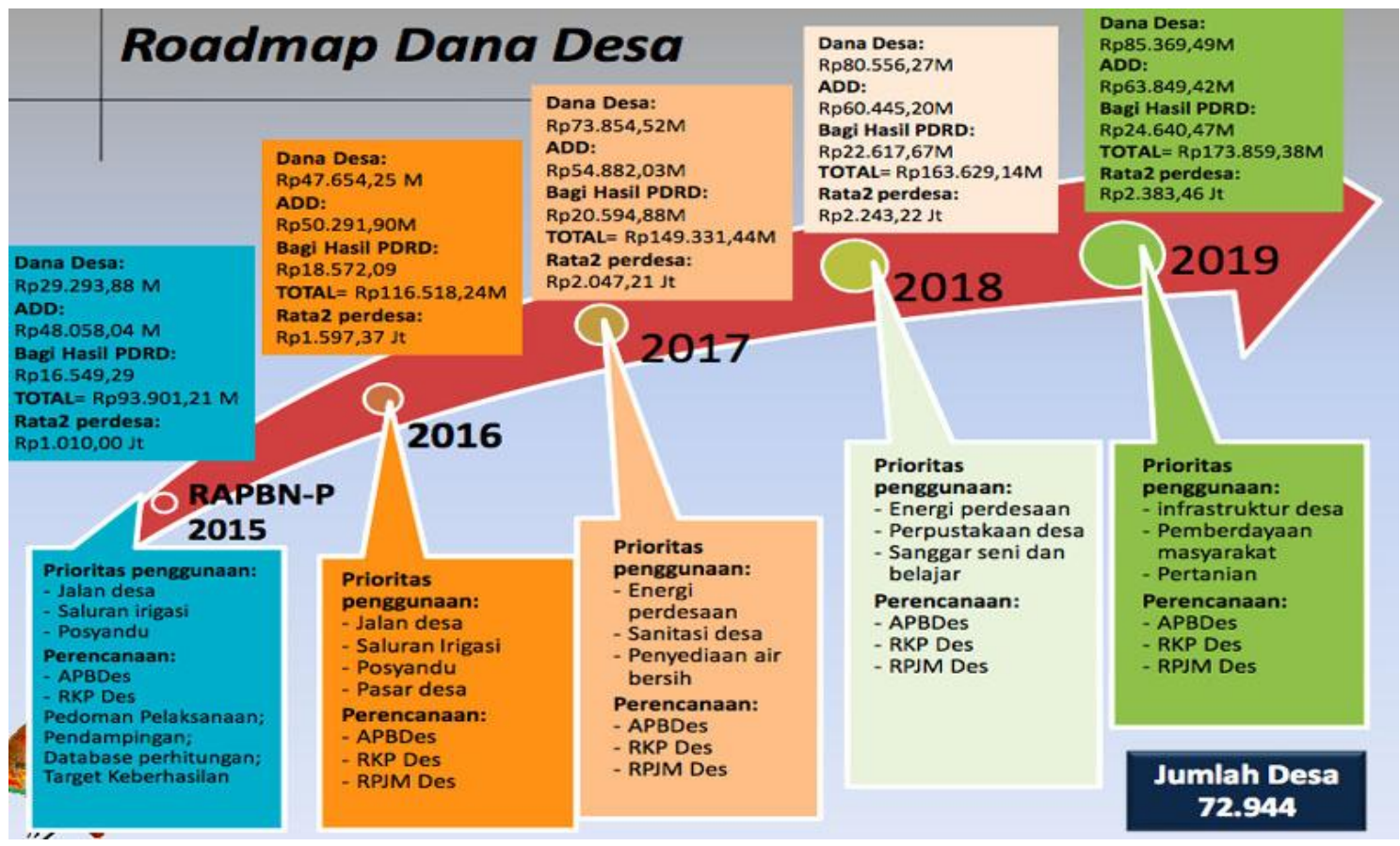

Gambar 3. Roadmap Dana Desa 2015-2019

Sumber: http://kppnmetro.org/dana-desa/ (Diunduh 22 Desember 2016).

\section{Sintesis:}

\section{Upaya Merumuskan Hakikat "Membangun dari Pinggiran"}

"Membangun dari pinggiran" berciri memberikan prioritas tinggi pada daerah pinggiran sebagai lawan dari daerah pusat. Daerah pusat adalah daerah yang selama ini dikenal sebagai tempat berlangsungnya kegiatan-kegiatan ekonomi yang paling intensif. Belum ada definisi baku yang secara ketat membatasi makna "daerah pinggiran". Namun demikian, secara intuitif makna itu dapat dijelaskan dengan ilustrasi-ilustrasi. Daerah pusat adalah Pulau Jawa, daerah pinggiran adalah daerah di pulau-pulau lainnya. Daerah pusat adalah Kawasan Barat Indonesia, daerah pinggiran adalah Kawasan Timur Indonesia. Daerah pusat adalah kawasankawasan perkotaan yang didominasi oleh industri manufaktur, daerah pinggiran adalah kawasan-kawasan pedesaan (kabupaten) yang didominasi oleh sektor pertanian. Daerah pusat adalah daerah ibukota negara dan sekitarnya, daerah pinggiran adalah wilayah perbatasan antara Indonesia dengan negara-negara tetangga.

Selanjutnya dapat dikemukakan adanya dua modus utama yang digunakan untuk penerapan kebijakan "membangun dari pinggiran", yakni: (1) menggerakkan kegiatan ekonomi di daerah-daerah pinggiran, khususnya pedesaan, dan (2) membuka atau membangun konektivitas antarwilayah khususnya konektivitas antara daerah pinggiran dengan daerah pusat tempat berlangsungnya kegiatan-kegiatan ekonomi secara intensif. Pengembangan konektivitas dilakukan dengan pembangunan infrastruktur khususnya yang berkaitan dengan sarana dan prasarana transportasi.

Sesungguhnya kerangka kebijakan tersebut selaras dengan rekomendasi yang disarankan oleh laporan hasil studi Bank Dunia (World Bank, 2009), yang mengkaji pengalaman berbagai negara dalam pembangunan regional. Dalam laporan tersebut geografi ekonomi suatu negara dipandang sebagai rangkaian kesatuan (kontinum) kepadatan penduduk yang memunculkan portofolio (alokasi fungsi-fungsi) tempattempat yang saling terkait. Kata kuncinya adalah simbiosis, yakni hidup bersama dalam harmoni dan sinergi. Di puncaknya adalah kota terbesar dari sebuah negara, dan di bawahnya terdapat spektrum permukiman-kota-kota 
sekunder, pusat urban kecil, kota kecil, dan pedesaan.

Bank Dunia menyusun klasifikasi perwilayahan berdasarkan tingkat urbanisasi, yakni urbanisasi awal (wilayah dengan status urban kurang dari 25\%), urbanisasi menengah (sekitar $50 \%$ bersifat urban), dan urbanisasi lanjut (lebih dari $75 \%$ bersifat urban). Tiap tingkat urbanisasi perlu memperoleh perlakuan dari instrumen kebijakan regional yang khas. Kebijakan regional pada wilayah dengan tingkat urbanisasi awal perlu menekankan upaya pembangunan institusi untuk membangun kepadatan. Upaya ini dimaksudkan untuk menciptakan penghematan akibat konsentrasi (economies of concentration). Ada ambang batas bawah bagi tingkat kepadatan kegiatan-kegiatan ekonomi yang produktif yang perlu dipenuhi oleh sebuah wilayah agar supaya mampu berkembang. Bank Dunia menyebut beberapa kata kunci untuk upaya membangun kepadatan ini, yakni hak atas tanah, pendidikan dasar, air bersih, dan sanitasi. Penjaminan hak atas tanah dan penyediaan infrastruktur dasar untuk pendidikan dan kesehatan merupakan prasyarat bagi suatu wilayah dengan tingkat urbanisasi awal untuk memperoleh manfaat dari economies of concentration.

Wilayah dengan tingkat urbanisasi menengah tetap perlu berupaya membangun kepadatan namun perlu ditambahi dengan upaya mengurangi jarak dengan membangun infrastruktur transportasi. Penghematan akibat konsentrasi dapat dipilah menjadi economies of localization (skala unit usaha yang besar dapat menciptakan penghematan), economies of agglomeration (berkumpulnya kegiatankegiatan usaha sejenis akan menurunkan biaya produksi), dan economies of urbanization (berkumpulnya kegiatan usaha berbagai jenis akan menurunkan biaya produksi). Penghematan-penghematan tersebut melahirkan surplus produksi, artinya hasil produksi di wilayah itu jauh lebih besar daripada yang dibutuhkan oleh konsumen-konsumen setempat. Oleh karena itu, pengangkutan surplus produksi tersebut ke luar wilayah itu perlu diperlancar dengan penyediaan infrastruktur transportasi yang memadai.

Adapun wilayah dengan tingkat urbanisasi lanjut juga masih tetap perlu berupaya membangun kepadatan (misalnya melalui regulasi penggunaan lahan dan peningkatan mutu penyediaan layanan dasar) dan mengurangi jarak (misalnya melalui peningkatan mutu manajemen logistik), namun perlu ditambahi dengan upaya menghapuskan penyekatan-penyekatan. Yang dimaksudkan dengan penyekatan di sini adalah gejala-gejala munculnya kawasan kumuh di perkotaan yang lazimnya disertai dengan peningkatan kejahatan-kejahatan dan persoalan-persoalan lainnya yang khas kota besar. Berbagai regulasi yang mengandalkan prinsip insentif dapat digunakan untuk mengelola berbagai persoalan yang khas kota besar tersebut.

Dalam kaitannya dengan kebijakan "membangun dari pinggiran" dapat ditafsirkan bahwa yang kini tengah diupayakan adalah membangun kepadatan, yakni mencapai ambang batas minimum tingkat kepadatan kegiatan-kegiatan produktif pada suatu wilayah, khususnya wilayah pinggiran, agar bisa tercipta surplus produksi yang kompetitif untuk dipasokkan ke wilayah lain. Serentak dengan itu digalakkan pembangunan infrastruktur dasar khususnya untuk mendorong konektivitas antarwilayah, yakni pembangunan prasarana angkutan seperti jalan darat, pelabuhan laut, dan pelabuhan udara.

Persoalan muncul sewaktu kriteria daerah pinggiran harus dirumuskan secara teknis. Agaknya yang telah ditempuh adalah pelaksanaan penyaluran dana desa dengan sasaran semua desa sebagaimana yang telah dibahas pada bagian awal artikel ini. Di satu pihak hal ini dapat dipahami sebagai pelaksanaan asas desentralisasi pembangunan. Namun di lain pihak hal ini dapat menimbulkan beberapa pertanyaan yang jawabannya dapat dihasilkan dari penelitian-penelitian empiris. Pertama, mana yang lebih efektif dari sudut pandang teori pembangunan wilayah (untuk tujuan pertumbuhan ekonomi atau pun tujuantujuan pembangunan yang lain), menyebarkan 
dana investasi publik (dana desa) secara merata ke semua desa atau menanamkan investasi publik di beberapa titik wilayah yang paling potensial responsif terhadap investasi? Kedua, dari sudut pandang pengelolaan anggaran negara, apakah menggelontorkan dana desa yang sedemikian besar sudah merupakan pilihan optimal? Ketiga, dari sudut pandang kemampuan aparat desa dalam mengelola anggaran yang sedemikian besar, sudahkah dipersiapkan secara memadai?

\section{CATATAN PENUTUP}

Pembahasan dalam tulisan ini hanya melibatkan pertimbangan-pertimbangan dari sudut pandang Ilmu Ekonomi Regional. Padahal pilihan kebijakan "membangun dari pinggiran" mencakupi dimensi-dimensi lain termasuk dimensi pertimbangan Ilmu Ekonomi Politik. ${ }^{6}$ Kebijakan itu tentu sedikit atau banyak mempunyai landasan pertimbangan upaya percepatan pemerataan pembangunan antarwilayah yang dirasakan situasinya sudah mencapai taraf mengkhawatirkan.

Kebijakan itu juga punya dimensi upaya memperkuat integrasi bangsa melalui peningkatan keadilan sosial bagi seluruh rakyat Indonesia. Dari sudut pandang ketahanan nasional, kebijakan itu juga dapat memperkuat daerah-daerah pinggiran yang langsung berbatasan dengan wilayah negara tetangga, melalui peningkatan kesejahteraan ekonomi masyarakat Indonesia yang tinggal di wilayahwilayah itu.

Sebagai catatan penutup yang terakhir, perlu ditekankan bahwa pembahasan dalam tulisan ini terbatas kemampuan prediksinya oleh karena tidak melibatkan analisis data empiris (hard evidence). Oleh karena itu, penelitian yang lebih mendalam dengan melibatkan analisis empiris dapat disarankan dilaksanakan sebagai tindak lanjut studi ini. Sudah dapat dipastikan bahwa studi empiris bidang ini di satu pihak sangat bermanfaat,

6 Periksa Crane (2006) untuk diskusi tentang koordinasi pusat-daerah dalam perencanaan dan keuangan konteks pra-desentralisasi. namun di lain pihak masih terkendala oleh ketersediaan data yang terbatas karena memang kebijakan ini belum berumur panjang.

\section{Ucapan Terima Kasih}

Penulis menyampaikan terima kasih kepada dua penelaah anonim dan editor yang telah memberikan saran-saran perbaikan. Kesalahan yang mungkin masih ada dalam artikel ini sepenuhnya menjadi tanggung jawab penulis.

\section{DAFTAR PUSTAKA}

Capello, R. \& Fratesi, U. (2011). Globalization and Regional Growth in Europe: Past Trends and Future Scenarios. Springer-Verlag, Berlin Heidelberg.

Capello, R. (2009). Regional Growth and Local Development Theories: Conceptual Evolution over Fifty Years of Regional Science. Geografie, Economie, Societe, 11 (1), 9-21.

Capello, R. (2016). Regional Economics. Edisi kedua. New York: Routledge.

Corbridge, S., \& Jones, G. A. (2009). The Continuing Debate About Urban Bias: The Thesis, Its Critics, Its Influence, and Implications for Poverty Reduction. Department of Geography and Environment, London School of Economics and Political Science.

Crane, R. (2006). The practice of regional development in Indonesia: Resolving centrallocal coordination issues in planning and finance. Public Administration and Development, 15 (2), 139-149.

Hill, H. (Editor). (2014). Challenges for Indonesia's Periphery. Singapore: ISEAS Publishing.

Marcus, A., \& Asmorowati, S. Urban Poverty and the Rural Development Bias: Some Notes from Indonesia. Journal of Developing Societies, 22 (2), 145-168,

Priyarsono, D. S. (2014). Beberapa Masalah dan Kebijakan Publik tentang Infrastruktur: Tinjauan dari Perspektif Ilmu Ekonomi. Orasi Ilmiah Guru Besar IPB. Bogor: IPB Press. 
Priyarsono, D. S. (2016). The Jokowi's “To Develop From The Periphery" Policy: How Effective?" Review of Indonesian Economic and Business Studies, 7 (1), 47-59,

Stimson, R. J., Stough, R. R., \& Roberts, B. H. (2006). Regional Economic Development: Analysis and Planning Strategies. SpringerVerlag, Berlin Heidelberg.

World Bank. (2009). Laporan Pembangunan Dunia 2009: Menata Ulang Geografi Ekonomi. Jakarta: Salemba Empat. 